Angelina Pavlović ${ }^{1}$ Saša Jovanović Slobodan Savić Danijela Nikolić Jasmina Skerlić

\section{ANALYSIS OF NATURAL GAS CONSUMPTION IN HOUSESHOLDS}

Abstract: Modern lifestyle is based on the consumption of various types of energy. Natural gas, as a mixture of gas hydrocarbons with methane $\left(\mathrm{CH}_{4}\right)$ predominating, is a commonly used source of energy which has significant technological and economic advantages compared to other conventional fuels. This paper analyses natural gas consumption in households, in residential areas with one and multi-family houses in the city of Kragujevac. This study involved residential units with different exposition (north and south) located in two streets, as well as one multi-family residential building with a neutral orientation. Natural gas consumption was studied for a period of ten years (20062015), with a comparative review of the deviation of some meteorological parameters from the normal values (cloudiness and mean daily temperature on a monthly basis). For the purpose of this study, the survey was conducted among the residents of these buildings and some of the results of the survey are presented in this paper. The survey questions were related to the valorization of residents' habits and characteristics relevant to the consumption of energy.

Keywords: Energy, Natural gas consumption, Households.

\section{Introduction}

Natural gas or fossil gas is considered as non-renewable fuel. That can be explained by the fact that natural gas was formed from the remains of microscopic animals and plants that died millions years ago ("Natural Gas Explained", 2018). Natural gas is used faster than it can be renewed.

Natural gas is a mixture of different gases which are rich in hydrocarbons. The chemical composition of the gas depends on the place where its exploitation is carried out. The dominant constituent of natural gas is the methane (Younger, 2004). The methane represents an extremely valuable energy source and chemical raw material that has significant technological, economic and environmental benefits in comparison to conventional fuels. Besides, methane is an important greenhouse gas generated dominantly by methanogens at low temperatures and through the breakdown of organic molecules at high temperatures (Stolper et al., 2014 ). According to that, there are three types of methane that can be found in the natural gas:

- Thermogenic methane,

- Abiogenic methane, and

- Biogenic methane.

Thermogenic and abiogenic methane are classified as non-renewable energy sources, because their precise reserves below the Earth's surface, are not known. Also, the processes of extraction of these gases are expensive. On the other hand, biogenic methane is defined as a renewable and sustainable source of energy because microorganisms create this type of methane 
by performing their natural activities throughout their life cycle.

Natural gas is almost ideal fuel that is easily mixed with air and it has a high combustion rate without smoke, soot and particulate matter. The combustion of natural gas, releases very small amounts of pollutants into the atmosphere. The combustion of natural gas has the smallest $\mathrm{CO}_{2}$ emission per unit of generated energy compared to other fossil fuels (Pulek-Kostić, 2015).

Nowadays, natural gas is used in a wide variety of applications and different sectors (industrial, transportation, buildings, electric power, etc.).

Although natural gas is an efficient fuel, it is necessary to reduce its consumption because it is generally regarded as a non-renewable source of energy.

Considering that the aim of this paper is to conduct an analysis of the consumption of natural gas. The analysis is done in certain streets in the territory of the city of Kragujevac. Also, climate impacts on natural gas consumption is the part of conducted analysis. According to analysis, measures for reducing consumption of gas in

Kragujevac

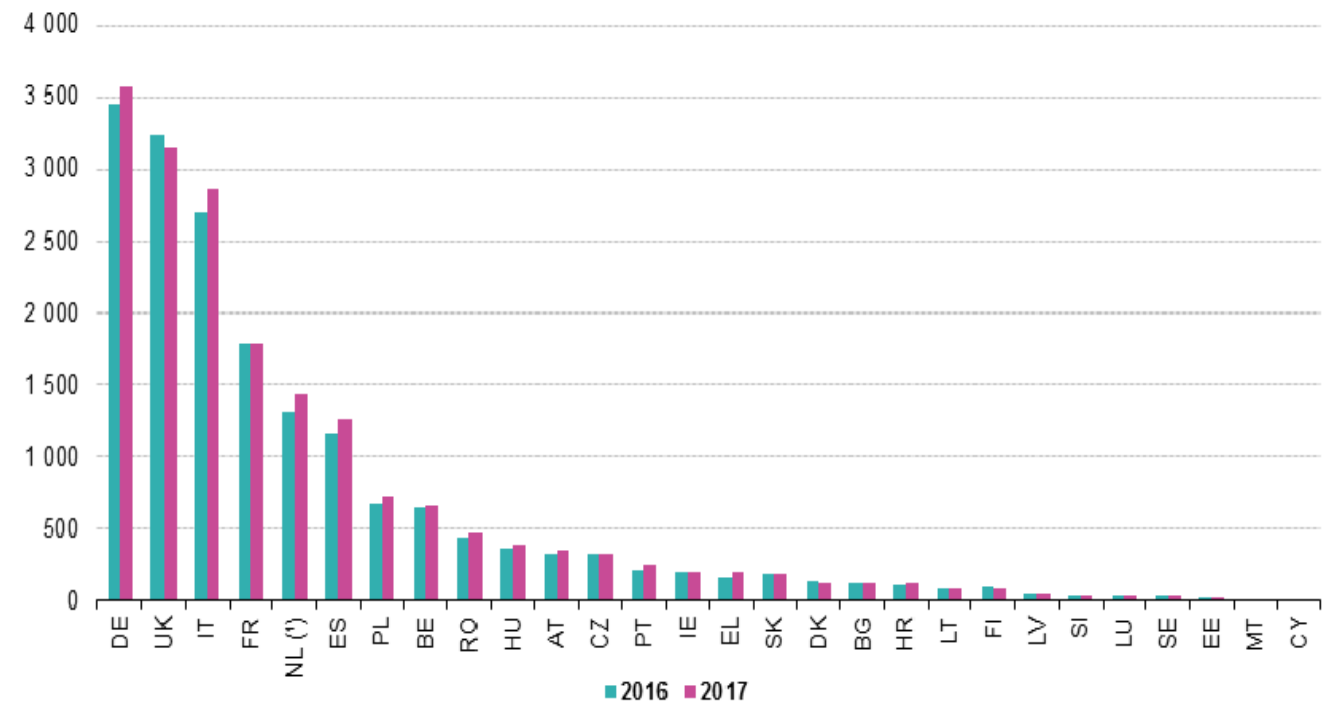

Figure 1. Gross inland consumption of natural gas by country (European Commission, 2018)

\section{Natural gas consumption}

In the available literature, there is a large amount of research about natural gas consumption.

Natural gas is the world's fastest growing fossil fuel, increasing by $1.4 \%$ per year, compared with liquid's $0.7 \%$ per year growth and virtually no growth in coal use $0.1 \%$ per year (EIA, 2017).

If we consider energy consumption in the European Union (EU), it can be concluded that the EU, as an intergovernmental and supranational union, has a great influence on the reduction of consumption non-renewable energy sources. By the establishment of legislation in the field of non-renewable energy sources, ie limitations, the entire European continent can achieve numerous social and economic benefits as well as ecological. Namely, the more efficient management of conventional forms of energy and promoting renewable forms of energy would minimize the negative pressure on the environment. 


\section{International Quality Conference}

Based on last avaiable data which is collected, processed and published by the European Commission, it can be concluded that in 2017, gross inland consumption of natural gas in the EU increased by $3.7 \%$ compared with 2016 (European Commission, 2018). The most increase in gas consumption was identificated in Portugal, Greece and Croatia, while the highest drop was indentificated in Sweden, Latvia, Finland and Estonia, as shown in Figure 1 on the previous page. In the Republic of Serbia for the purpose of meeting the energy needs of the population, natural gas is used. The supply structure of natural gas in Serbia consists of domestic and imported gas. Most domestic excavations are located in the territory of Vojvodina, while most of the missing gas quantities are compensated by imports from Russia, based on a long-term contract. The imported gas is available for Serbia since 1979 from one direction: from the north, through Hungary (Brkić \& Tanasković, 2017). The activities of natural gas distribution in Serbia are performed by the public company "Srbija Gas", which began to develop at the end of the last and at the beginning of this century. Gas is distributed to households and economic entities in around 60 municipalities. The length of the distribution network is $6,033.00 \mathrm{~km}$, and the map of the gas-pipeline is shown in Figure 2 ("SrbijaGas", 2019).

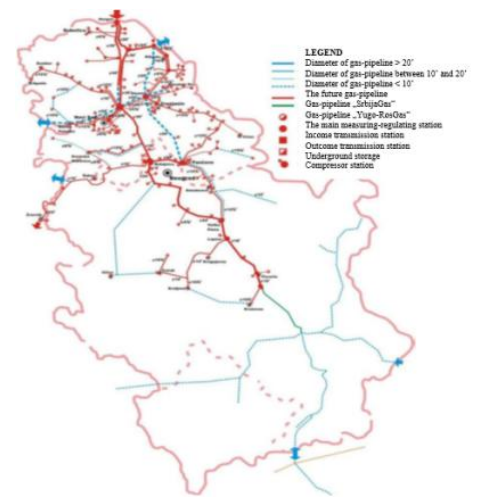

Figure 2. Map of gas network in Serbia
In the Republic of Serbia, even more than 90,000 households are connected to a distribution gas network. The distribution gas network in Serbia is organized into eight work units: Kikinda, Pančevo, Zrenjanin, Novi Sad, Belgrade, Jagodina, Kragujevac, Čačak.

\section{Climate impacts on natural gas consumption}

Builing energy consumption at the global level is $20-40 \%$ of total energy consumption, but in the Republic of Serbia, buildings are mostly non-energy efficient and they consumed about 50\% of total energy consumption (Nikolić et al., 2018).

Building energy consumption depends on a number of factors such as: the thermal insulation of object and its geometry, characteristics of HVAC systems (heating, ventilation, air conditioning), type of energy sources, levels of automatic regulation, the regime of use and maintenance of facilities and technical systems, price of energy, etc.

The above-mentioned factors are internal factors that have an influence on energy consumption. In addition to them, the energy consumption in one object is affected by climate factors, so-called external factors. Climatic factors are determined by the location on which the object is situated. For example, climatic factors are air temperature, cloudiness, wind exposure, etc.

This paper presents the analysis of the impact of climate conditions on the consumption of natural gas in the city of Kragujevac during the ten-year period from 2006 to 2015 . Gas consumption is analysed in selected streets of different exposures, located in the territory of the city of Kragujevac.

The altitude in Kragujevac is in the range of 170 to 240 meters. The climate of the city is characterized by a moderate continental climate with all four seasons: spring, summer, autumn, winter (Đorđević et al., 


\section{(2) \\ 13 106 \\ QUA UI UV}

IDIFSIFAIDCI

2014). The impact of the mean monthly air temperature and the mean monthly cloudiness was taken into account in the analysis. The mean monthly air temperatures and the mean monthly cloudiness for the

considered period 2006-2015 is shown by Figure 3 and Figure 4. According to data of Republic hydrometeorological service of Serbia, Figure 3 and Figure 4 are created (RHMZ, 2019).

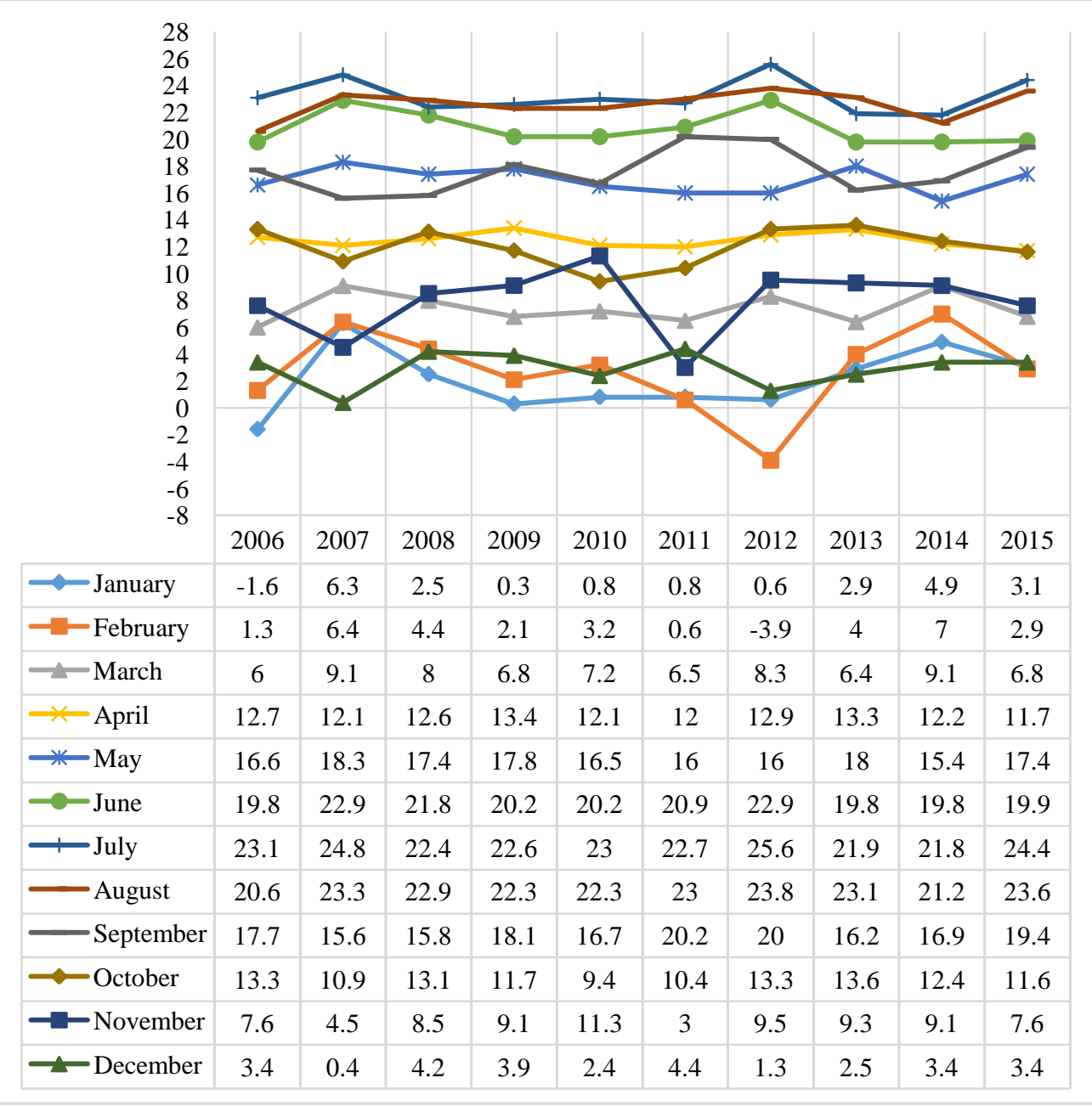

Figure 3. The mean monthly air temperature in the city of Kragujevac for the period from 2006 to $2015\left[{ }^{\circ} \mathrm{C}\right]$ 


\section{Intermational Quality Conference}

$13^{\text {th }} 100$

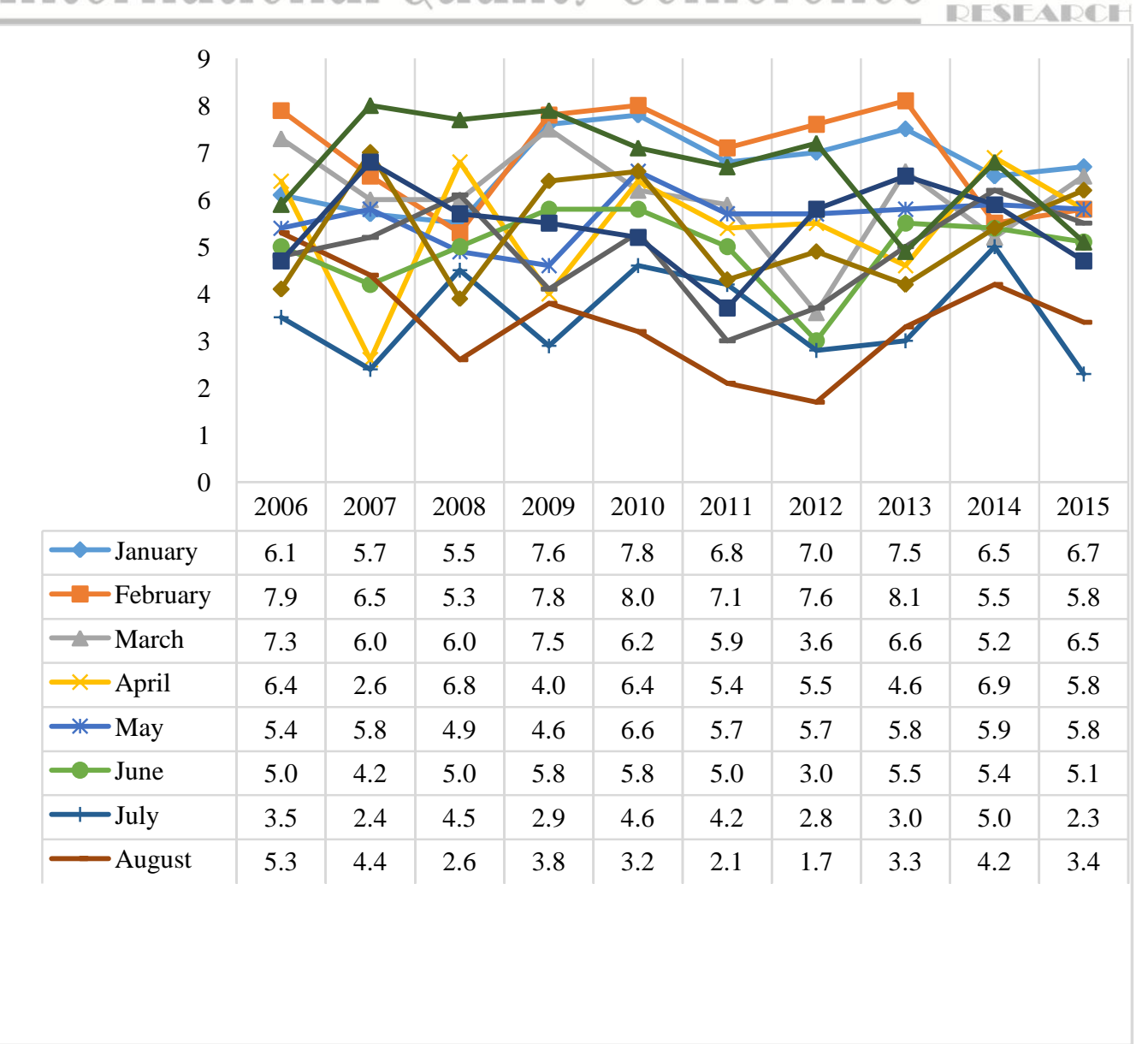

Figure 4. The mean monthly cloudiness in the city of Kragujevac for the period from 2006 to 2015 [okta]

\section{Natural gas consumption in the city of Kragujevac}

The distribution of natural gas in the territory of the city of Kragujevac is performed by the public company "Srbija Gas" through the work unit: Kragujevac.

During the analysed consumption of natural gas in the territory of the city of Kragujevac, the facilities in Žarka Zrenjanina Street and in Kolubarska Street were considered. Also, the analysis includes the consumption of natural gas of a residential multi-storey building in Aleksandra I Karađorđević
Street.

The gas consumption is analysed in the streets with different exposition (north and south) while the residential multi-storey building has a neutral orientation.

Locations of streets where natural gas consumption is analysed are marked on the map. That map is shown in Figure 5 on the next page . 


\section{Intermational Qualility Conference}

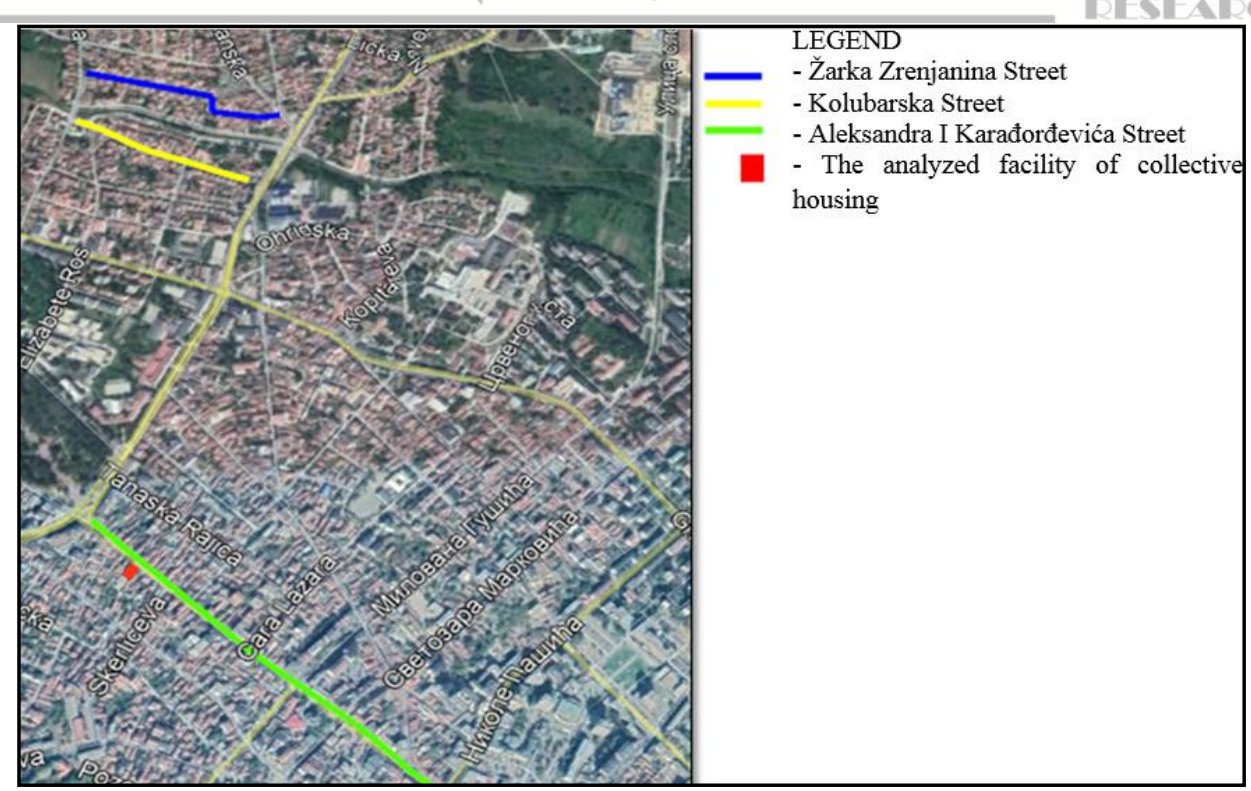

Figure 5. Location of streets where natural gas consumption is analysed

The consumption of natural gas in one consumer will be shown. The households depends on numerous factors. One of those is consumer behavior because that is the most important issue with respect to energy consumption in households. Except that, weather or climatic conditions in a particular territory has a big influence on energy consumption, as already said.

Throughout the analysis of consumption of gas, the data about consumption were collected for a total of 93 households, as follows:

- Žarka Zrenjanina Street - 30 households,

representative example has the aim to show typical information about consumers of natural gas which are used for the research. The representative consumer is a consumer with code 0301-02620-1 which is selected by random choice.

The consumption of natural gas for household 0301-02620-1 was 48,823.00 $\mathrm{m}^{3}$ for the ten years period. For the same household, monthly consumption of gas for every year (2006-2015) is shown in Figure 6.

On the other hand, the natural gas consumption, the mean monthly air temperature, and the mean monthly cloudiness are presented in Figure 7. That data is shown for 2012 because it is a year with the lowest air temperatures during the analysed period.

Increases and decreases in the gas consumption depending on the deviations of the mean temperature from the normal (average) values are also indicated (Jovanović et al., 2015). In periods of strong and long-lasting cold spells in the winter months, there is increased gas consumption as a result of heating in residential and office 


\section{Intermational Qualitity Conference}

buildings. In Figure 7, February of 2012 was identified as critical month because there was an increase in gas consumption. That is a consequence of low temperature and high cloudiness.

\begin{tabular}{|c|c|c|c|c|c|c|c|c|c|c|}
\hline \multicolumn{11}{|l|}{1600} \\
\hline \multicolumn{11}{|l|}{1400} \\
\hline \multicolumn{11}{|l|}{1200} \\
\hline \multicolumn{11}{|l|}{1000} \\
\hline \multicolumn{2}{|l|}{800} & \multicolumn{9}{|c|}{600} \\
\hline 400 & & & & & & & & & & \\
\hline 200 & & & & & & & & & 1 & \\
\hline 0 & 2006 & 2007 & 2008 & 2009 & 2010 & 2011 & 2012 & 2013 & 2014 & 2015 \\
\hline January & 1056 & 394 & 536 & 692 & 1038 & 784 & 1480 & 1180 & 760 & 761 \\
\hline February & 871 & 474 & 501 & 604 & 778 & 586 & 1520 & 806 & 756 & 843 \\
\hline March & 859 & 511 & 394 & 563 & 466 & 710 & 1161 & 868 & 454 & 682 \\
\hline April & 297 & 239 & 230 & 169 & 259 & 376 & 684 & 461 & 294 & 295 \\
\hline May & 88 & 59 & 105 & 134 & 144 & 168 & 269 & 126 & 206 & 164 \\
\hline June & 135 & 57 & 56 & 70 & 62 & 110 & 245 & 105 & 128 & 138 \\
\hline July & 0 & 52 & 61 & 95 & 88 & 93 & 150 & 116 & 124 & 119 \\
\hline August & 0 & 58 & 74 & 101 & 79 & 81 & 111 & 75 & 100 & 115 \\
\hline September & 43 & 139 & 135 & 72 & 88 & 77 & 156 & 132 & 146 & 111 \\
\hline October & 86 & 266 & 295 & 275 & 332 & 319 & 318 & 356 & 269 & 325 \\
\hline November & 470 & 676 & 381 & 460 & 442 & 1349 & 584 & 385 & 655 & 587 \\
\hline December & 687 & 593 & 501 & 759 & 718 & 1272 & 943 & 886 & 1136 & 746 \\
\hline
\end{tabular}

Figure 6 . The monthly consumption of natural gas $\mathrm{m}^{3}$ in the observed period (consumer 0301-02620-1 )

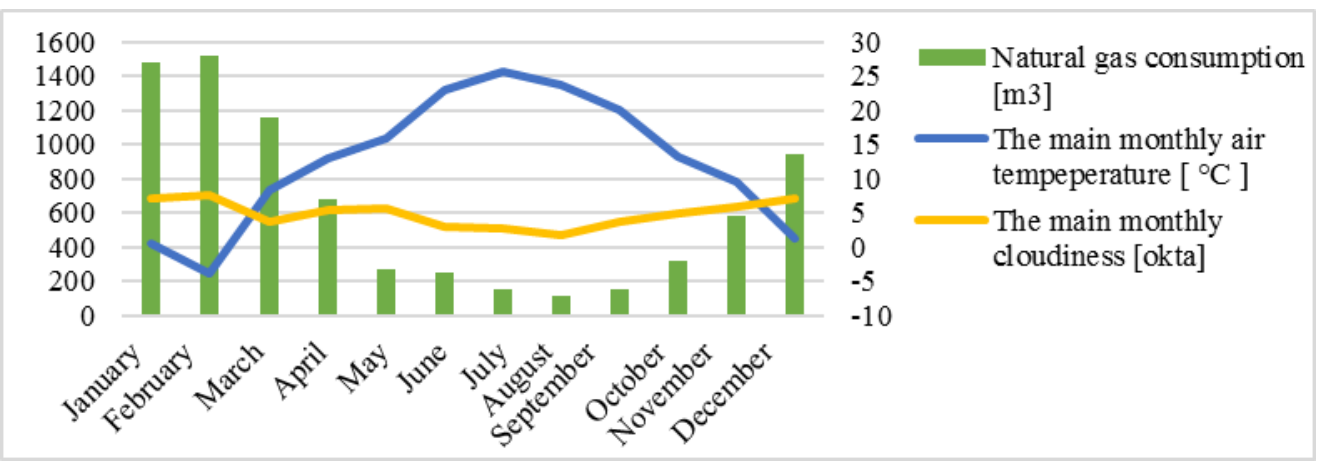

Figure 7. The effect of the change in the mean air temperature and cloudiness on gas consumption $\mathrm{m}^{3}$ for 2012 (consumer 0301-02620-1) 


\section{Survey of natural gas consumption in households and its results}

Consumer surveys are the traditional instrument of statisticians to collect data on household energy consumption.

The survey was conducted in order to collect certain data, which are directly related to the consumption of gas, such as the number of household members, the number of hours which members spend in the facility, the position of the facility, the existence of optimum insulation, etc.

Survey of natural gas consumption in households was conducted in the streets and facilities for which the analysis of consumption was done.

Based on the collected data, the number of household members in the largest percentage is from 1 to 3 members (29.69\%), while 3 to 5 members live in $23.44 \%$ of households. The smallest percentage is represented by households with more than 5 members $(14.84 \%)$. In $32.03 \%$ of households, there is no available information about the average number of members. The listed data is shown in Figure 8.

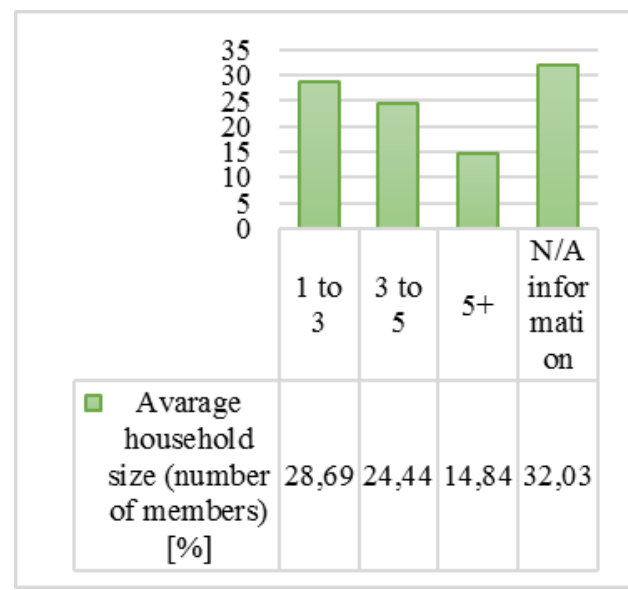

Figure 8. Number of members in households [\%]

When it comes to heated living areas, the survey aimed to identify only the area of heating rooms, ie the floor area of a dwelling that is heated during most of the winter months. The results of this part of the survey is shown in Figure 9.

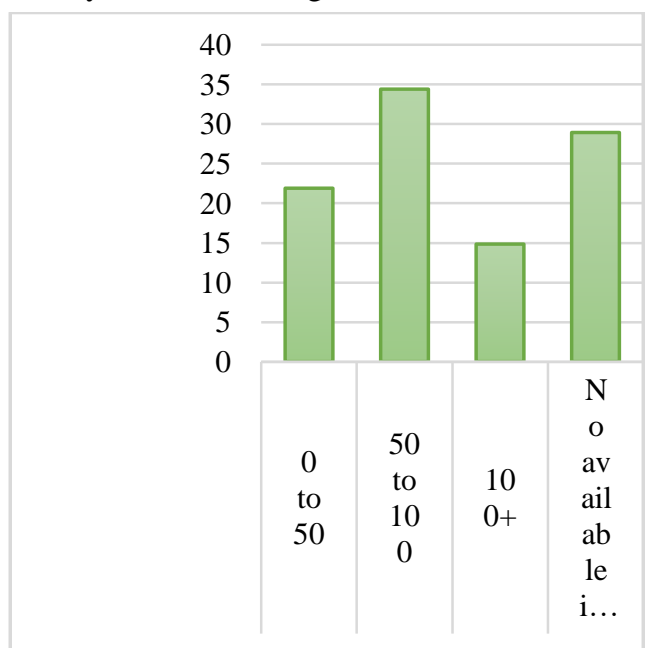

Figure 9. Avarage of heated living areas $\mathrm{m}^{2}$ [\%]

As already mentioned, gas can be used for different purposes. In the largest number of analysed households, gas is used for heating or in combined purpose, as it shown in Figure 10. The analysed consumers view the combined use of gas as one of the benefits of this fossil energy source.

Gas is used as a source of energy in the household for...

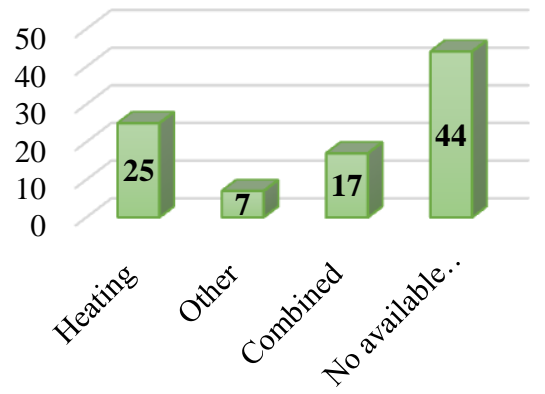

Figure 10. Uses of natural gas in analysed households [number of households] 


\section{Intermational Quality Conference}

\section{Conclusion}

Sustainable development is no longer just a term used in literature. Today, it becomes an integral part of many legal standards. Energy efficiency is recognized worldwide as the fastest and the cheapest way of achieving different goals of sustainable development.

Energy security, among other things, can be achieved by energy saving. The use of energy is in correlation with environmental pollution. That means, reduced energy consumption has positive influences on the reduction of various forms of environmental pollution.

Natural gas during the analysed period was one of the cheapest energy sources. With the comfort that provides to users and its price, natural gas represents the best choice of energy products on the market of the Republic of Serbia. In order to reduce the consumption and to increase savings of this natural resource, it is necessary to analyse the influence of a large number of different factors.

During the design process of residential buildings, it is possible to make appropriate adjustments of gas consumption to urban, climatic and geographic parameters. Also, through the analysis of affecting consumer behavior on gas consumption, there is a possibility of improvement in this sector, as well. At the same time, it is the suggested measure for reducing the consumption of gas in Kragujevac. It is necessary to affect consumer awareness in order for him to understand the negative side of using nonrenewable energy sources

Acknowledgment: This investigation is a part of the project TR 33015 of Technological Development of the Republic of Serbia. We would like to thank to the Ministry of Education and Science of Republic of Serbia for the financial support during this investigation.

\section{References:}

Brkić, D., Tanasković, T. (2008). Systematic approach to natural gas usage for domestic heating in urban areas. Energy, 33 (12), pp.1738-1753. DOI: 10.1016/j.energy.2008.08.009.

Đorđević, S., et al. (2014). Strategija razvoja turizma grada Kragujevca 2015-2020. [Tourism Development Strategy of the city of Kragujevac 2015-2020]. Kragujevac, Republic of Serbia.

EIA - U.S. Energy Information Administration. (2017). International Energy Outlook 2017. Washington. Report number: DOE/EIA-0484:2017.

European Commission. (2018). Natural gas supply statistics - Statistics Explained. Retrieved from https://ec.europa.eu/eurostat/statisticsexplained/index.php?title=Natural_gas_supply_statistics\&oldid=401136.

Jovanović, S., Savić, S., Bojić, M., Đorđević, Z., Nikolić, D. (2015). The impact of the mean daily air temperature change on electricity consumption. Energy, Vol. 88, pp. $604-609$. ISSN 0360-5442, DOI 10.1016/j.energy.2015.06.001.

Natural Gas $\quad$ Explained. (2018). Retrieved from https://www.eia.gov/energyexplained/index.php?page=natural_gas home.

Nikolić, D., Skerlić, J., Cvetković, D., Radulović, J., Jovanović, S. (2018). Basic principles of passive solar heating. 3rd International conference on Quality of Life, Kopaonik, Serbia, 28 30.11., pp. 187-192, ISBN 978-86-6335-056-4. 
DIFSEALP

Pulek-Kostić, A. (2015). Prirodni (zemni) gas, Eksploatacija tečnih i gasovitih mineralnih sirovina i gasna tehnika. [Natural gas, Exploitation of liquid and gaseous mineral raw materials and gas technology]. Faculty of Mining and Geology, University of Belgrade, Republic of Serbia. Available online: http://www.rgf.bg.ac.rs/predmet/RO/V\%20semestar/Hemija\%20i\%20prerada\%20nafte\%20i \%20gasa/Predavanja/10predavanje\%20X.pdf

RHMZ - Republic hydrometeorological service of Serbia. Retrieved from www.hidmet.gov.rs/ .Srbija Gas. (2019). Retrieved from www.srbijagas.com.

Stolper, A., Lawson, M., Davis, C., Ferreira, A., Santos Neto, E., Ellis, G., Lewan, Martini, A., Tang, Y., Schoell, M., Sessions, A., Eiler, E. (2014). Formation temperatures of thermogenic and biogenic methane. Vol. 344, Issue 6191, pp. 1500-1503, DOI: 10.1126/science. 1254509

Younger, A. H. (2004). Natural Gas Processing Principles and Technology Part I, University of Calgary, Calgary, Alberta.

\section{Angelina Pavlović}

University of Kragujevac,

Faculty of Engineering

Kragujevac,

Serbia

djina1107@gmail.com

\section{Danijela Nikolić}

University of Kragujevac,

Faculty of Engineering

Kragujevac,

Serbia

danijelan@kg.ac.rs
Saša Jovanović

University of Kragujevac,

Faculty of Engineering

Kragujevac,

Serbia

dviks@kg.ac.rs

\section{Jasmina Skerlić}

University of Kragujevac,

Faculty of Engineering

Kragujevac,

Serbia

jskerlic@kg.ac.rs

\section{Slobodan Savić}

University of Kragujevac,

Faculty of Engineering

Kragujevac,

Serbia

ssavic@kg.ac.rs 